\title{
トリポード形等速継手の力学特性解析*
}

\author{
渡 辺 克 已*1, 川 勝勉*2 \\ 中尾彰一*2, 大原卓*3
}

\section{Analyses of Static Characteristics of Tripod Constant Velocity Joints}

\author{
Katsumi WATANABE**, Tsutomu KAWAKATSU, \\ Shouichi NAKAO and Taku OHARA \\ *4 Yamagata Univ., Faculty of Engineering, Dept. of Mechanical Systems Engineering, \\ Jounan 4-3-16, Yonezawa-shi, Yamagata, 992-8510 Japan
}

\begin{abstract}
In this paper, a procedure is established for solving simultaneously a set of thirty conditional equations with respect to forces and moments acting on three spherical rollers, the tripod and the housing of tripod constant velocity joints, which are cylindrical-paired and sphere-cylinder-paired respectively, for any values of friction coefficients between spherical rollers and its grooves and axes. Moreover, the rotational velocity of the spherical roller relative to the tripod and the condition for rolling motion of the spherical roller to change into sliding motion on its groove are deduced. The established numerical procedure simulates the normal force of the spherical roller and the groove thrust force with a period of $\pi$ and the housing thrust force with a period of $2 \pi / 3$ for given values of the joint angle. These results are inspected by experimental analyses.
\end{abstract}

Key Words : Tripod Joint, Constant Velocity Joint, Static Analysis, Housing Thrust Force, Friction Force

\section{1. 緒言}

しゅう動式トリポード形等速継手のハウジングのス ラスト力は 1 回転中に $2 \pi / 3$ 周期で変化することが解 析的検討および実験により知られている(1) (3). しか し, 構成部品である三つの球面ローラ, ハウジングお よびトりポードに作用する力とモーメントを釣合い条 件に基づいて解析することは試みられていない。ま た, 球面ローラがローラ軸に円筒対偶されている形式 のトリポード形等速継手の球面ローラは 1 回転中にハ ウジングのローラ溝に対して 1 摇動する.このため, 球面ローラとローラ溝およびローラ軸との摩擦状態が 周期的に変化して球面ローラはローラ溝上を転がった り，滑ったりする。この摩擦特性も解明されていな い.

本論文では, 球面ローラとローラ溝およびローラ軸 間の摩擦係数をパラメータとして, 三つの球面ローラ,

* 原稿受付 2000 年 1 月 20 日.

*1 正員, 山形大学工学部 (丞992-8510 米沢市城南 4-3-16).

*2 本田技研工業 (株)栃木製作所（画321-4346 真岡市松山町 19).

*3 正員, ファナック(株) (画401-0597 山梨県南都留郡忍野村 忍草字古馬場 3580 ).

E-mail : tb122@dip.yz.yamagata-u.ac.jp
ハウジングおよびトリポードに作用する力とモーメン トの釣合い条件式を導出する(4). そして球面ローラの ローラ軸に対する相対速度の算出式を与えてハウジン グスラスト力を含むトリポード形等速継手の力学特性 のシミュレーション法を確立する。さらに，一つの球 面ローラに作用する法線方向の力とローラ溝方向の力 を測定し，解析結果と比較検討することにより本論文 の手法の有効性を確認する。

\section{2. 力学モデル}

三つの球面ローラはハウジングのローラ溝と球面・ 円筒対偶されて扔り，トリポードのローラ軸に円筒対 偶されている.そしてハウジングの軸 (入力軸) は静止 節(フレーム)に回転対偶されており，端部にツェッパ 形等速継手が接続されるトリポード軸(出力軸)は静止 節に球面対偶されていると考える。

このとき, 三つの球面ローラ, 八ウジングおよびト リポードの対偶部に作用する力とモーメントの直交 3 成分の系をトリポード形等速継手の力学モデルと呼ぶ ことにする. 図 1 にトリポード形等速継手の内部構造 を示す。

$2 \cdot 1$ 力およびモーメントの作用方向 図 2 に示 すように, 入力軸の中心線上に原点 $\mathrm{O}$ を定め, 入力軸 
を $y$ 軸，それと直交する軸を $x$ 軸扔よび $z$ 軸とする 静止直交座標系を $\mathrm{O}^{-} x y z$ とする。 $x$ 軸, $y$ 軸および $z$ 軸の方向，向きを表す単位べクトルをそれぞれ $\boldsymbol{i}, \boldsymbol{j}$ お よび $\boldsymbol{k}$ とする。

出力軸の端点 $\mathrm{B}$ の座標を $\left(0, y_{B}, z_{B}\right)$ とする.また, トリポードの中心を $\mathrm{S}$, 点 $\mathrm{S}$ を通る出力軸の中心線の 球面座標を $\left(\xi_{2}, \eta_{2}\right)$ とし，その方向，向きを表寸単位 ベクトルを次のように表す。

$\boldsymbol{a}=\sin \xi_{2} \cos \eta_{2} \boldsymbol{i}+\sin \xi_{2} \sin \eta_{2} \boldsymbol{j}+\cos \xi_{2} \boldsymbol{k}$

出力軸と $z$ 軸方向に垂直な単位べタトルを出力軸 まわりに $-90^{\circ}$ 回転した単位べクトル $\boldsymbol{b}$ は

$\boldsymbol{b}=-\cos \xi_{2} \cos \eta_{2} \boldsymbol{i}-\cos \xi_{2} \sin \eta_{2} \boldsymbol{j}+\sin \xi_{2} \boldsymbol{k}$

と表される。

八ウジングの三つのローラ溝およびトリポードの三 つのローラ軸は等間隔に配置されているものとし，そ れらの角変位 $\phi_{m}$ 打よび $\phi_{m}(m=1 \sim 3)$ はそれぞれ 軸抢よび点 $\mathrm{B}$ を通り方向，向きが $\boldsymbol{b}$ の直線から反時 計回り方向に測るものとする。 そして第 1 番めのロー ラ溝の角変位 $\phi_{1}$ を入力角とし，第 1 番めのローラ軸

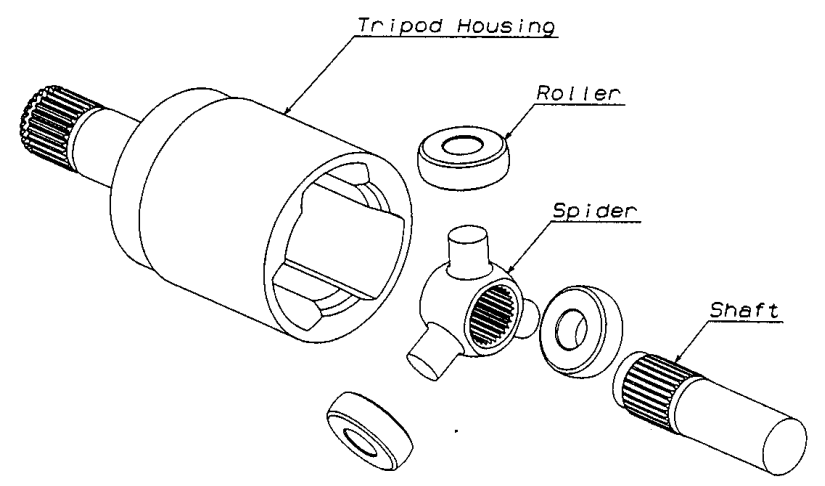

Fig. 1 Inner structure of the tripod constant velocity joint
の角変位 $\phi_{1}$ を出力角とする。

トリポードの第 1 , 第 2 おるび第 3 番めのローラ軸

の方向，向きを表す単位べクトルは次式で与えられる.

$$
\begin{aligned}
\boldsymbol{s}_{m} & =\cos \phi_{m} \boldsymbol{b}+\sin \phi_{m} \boldsymbol{i} \\
& =\left(\sin \phi_{m} \sin \eta_{2}-\cos \phi_{m} \cos \xi_{2} \cos \eta_{2}\right) \boldsymbol{i} \\
& -\left(\sin \phi_{m} \cos \eta_{2}+\cos \phi_{m} \cos \xi_{2} \sin \eta_{2}\right) \boldsymbol{j} \\
& +\cos \phi_{m} \sin \xi_{2} \boldsymbol{k} \ldots \ldots \ldots \ldots \ldots \ldots \ldots \ldots \ldots
\end{aligned}
$$

ハウジングの第 1 , 第 2 および第 3 番めのローラ溝 の方向およびそれらと直交する方向を表す単位べクト ルをそれぞれ $\boldsymbol{i}_{m}$ 抢よび $\boldsymbol{k}_{m}$ とすると，

$$
\left.\begin{array}{l}
\boldsymbol{i}_{m}=\cos \phi_{m} \boldsymbol{i}-\sin \phi_{m} \boldsymbol{k} \\
\boldsymbol{k}_{m}=\sin \phi_{m} \boldsymbol{i}+\cos \phi_{m} \boldsymbol{k}
\end{array}\right\}
$$

第 1 , 第 2 抢よび第 3 番めの球面口ーラの中心 $\mathrm{R}_{m}(m=1 \sim 3)$ の座標をそれぞれ $\left(x_{R m}, y_{R m}, z_{R m}\right)$ とす る。さらに, 球面ローラとローラ溝の接点 $\mathrm{C}_{1}, \mathrm{C}_{2}$ およ び $\mathrm{C}_{3}$ の座標をそれぞれ $\left(x_{c m}, y_{c m}, z_{c m}\right)(m=1 \sim 3)$ と する.

接点 $\mathrm{C}_{m}(m=1 \sim 3)$ のローラ溝上での円周方向の変 位の中心角を $\delta_{m}(m=1 \sim 3)$ とし, $\phi_{m}^{*}=\phi_{m}+\delta_{m}$ とおけ ば，球面ローラとローラ溝の共通接平面に垂直な方向， 向きを表す単位べクトルは次式で与えられる。

$$
\boldsymbol{n}_{m}=\frac{\overrightarrow{R_{m} C_{m}}}{\overrightarrow{R_{m} C_{m}}}=\cos \psi_{m}^{*} \boldsymbol{i}-\sin \psi_{m}^{*} \boldsymbol{k}
$$

球面口ーラの中心 $\mathrm{R}_{m}(m=1 \sim 3)$ を通り, 方向, 向 きが $\boldsymbol{n}_{m}$ および $\boldsymbol{j}$ で与えられる直線に直交する直線の 方向，向きを表す単位べクトルを $\boldsymbol{t}_{m}(m=1 \sim 3)$ とする と,

$$
\boldsymbol{t}_{m}=\boldsymbol{n}_{m} \times \boldsymbol{j}=\sin \phi_{m}^{*} \boldsymbol{i}+\cos \phi_{m}^{*} \boldsymbol{k}
$$

球面ローラの中心の軸と出力軸に直交する直線の方 向，向きを表す単位べクトルを $\boldsymbol{u}_{m}(m=1 〜 3)$ とすると,

$\boldsymbol{u}_{m}=\boldsymbol{a} \times s_{m}$ $=\left(\sin \eta_{2} \cos \phi_{m}+\cos \xi_{2} \cos \eta_{2} \sin \phi_{m}\right) \boldsymbol{i}$ $-\left(\cos \eta_{2} \cos \phi_{m}-\cos \xi_{2} \sin \eta_{2} \sin \phi_{m}\right) \boldsymbol{j}$

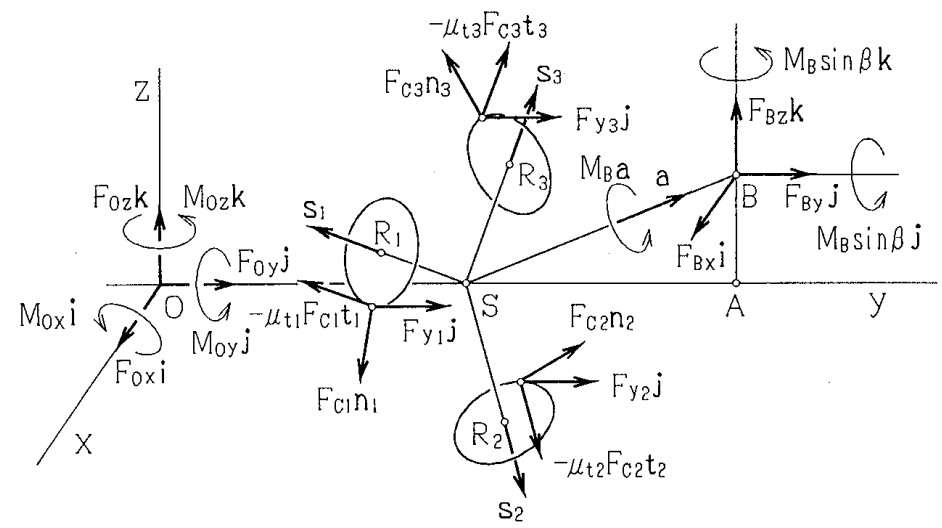

Fig. 2 Forces and moments acting on the tripod and the housing from the frame and forces acting on the housing from three spherical rollers 
$-\sin \xi_{2} \sin \phi_{m} k$

軸交差角を $\beta$ とし, 出力軸の球面座標 $\left(\xi_{2}, \eta_{2}\right)$ を

$$
\xi_{2} \fallingdotseq \frac{\pi}{2}-\beta, \quad \eta_{2} \fallingdotseq \frac{\pi}{2}
$$

と近似するときには $\boldsymbol{a}, \boldsymbol{b}, \boldsymbol{s}_{m}$ および $\boldsymbol{u}_{m}$ は次式となる。

$$
\begin{aligned}
\boldsymbol{a} & =\cos \beta \boldsymbol{j}+\sin \beta \boldsymbol{k} \\
\boldsymbol{b} & =-\sin \beta \boldsymbol{j}+\cos \beta \boldsymbol{k} \\
\boldsymbol{s}_{m} & =\sin \phi_{m} \boldsymbol{i}-\sin \beta \cos \phi_{m} \boldsymbol{j} \\
& +\cos \beta \cos \phi_{m} \boldsymbol{k} \\
\boldsymbol{u}_{m} & =\cos \phi_{m} \boldsymbol{i}+\sin \beta \sin \phi_{m} \boldsymbol{j} \\
& -\cos \beta \sin \phi_{m} \boldsymbol{k}
\end{aligned}
$$

$2 \cdot 2$ 構成部品に作用する力とモーメントの成分

フレームから入力軸に作用する $x$ 軸， $y$ 軸および $z$ 軸 方向の力およびこれらの軸まわりのモーメントをそれ ぞれ次のように表す(図 2 参照)。

$F_{O x} \boldsymbol{i}, F_{O y} \boldsymbol{j}, F_{O z} \boldsymbol{k}, M_{O x} \boldsymbol{i}, M_{O y} \boldsymbol{j}, M_{O z} \boldsymbol{k}$ ここで, $M_{0 y}$ は入力モーメントである.

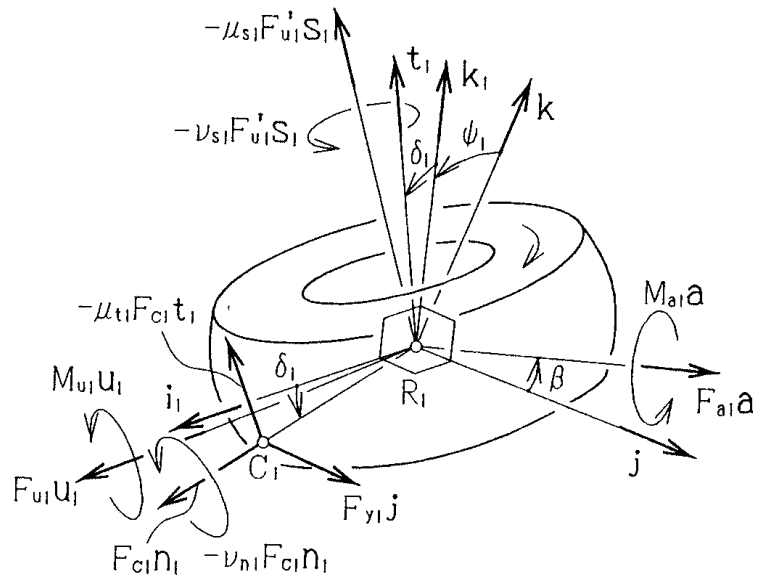

(a) In the case where the spherical roller is rolling

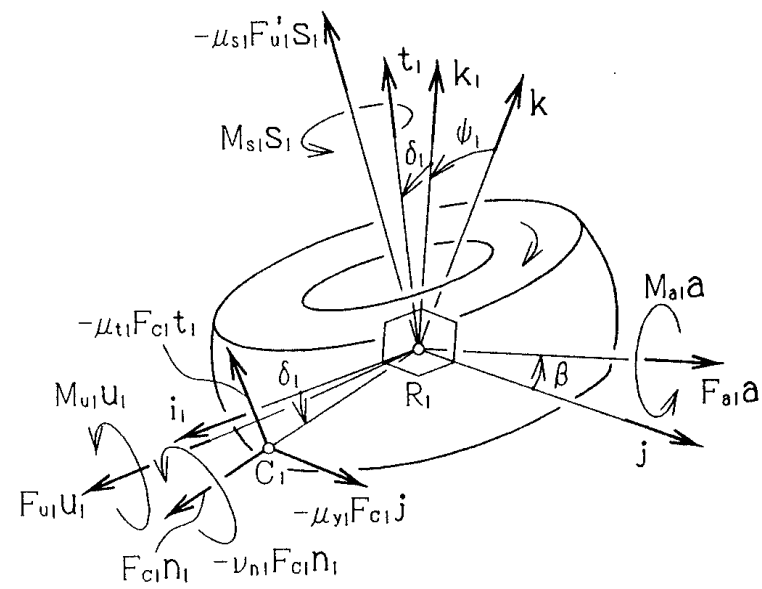

(b) In the case where the spherical roller is sliding

Fig. 3 Forces and moments acting on the tripod and the housing from the spherical roller
出力軸の端点 $\mathrm{B}$ に作用する $x$ 軸, $y$ 軸および $z$ 軸 方向の力执よび出力軸まわりのモーメント（出力モー メント)をそれぞれ次のように表す。

$F_{B x} \boldsymbol{i}, F_{B y} \boldsymbol{j}, F_{B z} \boldsymbol{k}, M_{B} \boldsymbol{a}$

八ウジングのローラ溝と球面ローラの接点 $\mathrm{C}_{m}(m=$ 1〜3) において, 球面ローラからハウジングに作用す る法線力，ローラ溝方向の反力およびローラ溝の円周 方向の摩擦力をそれぞれ次のように表す (図 3 参照).

$F_{C m} \boldsymbol{n}_{m}, \quad F_{y m} \boldsymbol{j}, \quad-\mu_{t m} F_{C m} \boldsymbol{t}_{m} \quad(m=1 \sim 3)$

さらに, 球面ローラとローラ溝の接触部の摩擦モーメ ントを

$-\nu_{n m} F_{c m} \boldsymbol{n}_{m} \quad(m=1 \sim 3)$

とする.

ここで, $\mu_{t m}$ および $\nu_{n m}(m=1 \sim 3)$ はそれぞれ球面 ローラとローラ溝間の円周方向運動および共通法線ま わりの回転運動の等価摩擦係数である.

球面ローラからそれらの中心 $\mathrm{R}_{m}(m=1 \sim 3)$ におい てローラ軸に作用する直交 2 方向の力およびモーメン トをそれぞれ次のように表す。

$F_{u m} \boldsymbol{u}_{m}, F_{a m} \boldsymbol{a}, M_{u m} \boldsymbol{u}_{m}, M_{a m} \boldsymbol{a} \quad(m=1 \sim 3)$

さらに, 球面ローラとローラ軸の円筒対偶部の摩擦 力および摩擦モーメントをそれぞれ

$$
\begin{aligned}
& -\mu_{s m} F_{u m}^{*} \boldsymbol{s}_{m}, \quad-\nu_{s m} F_{u m}^{*} \boldsymbol{s}_{m} \\
& F_{u m}^{*}=\sqrt{F_{u m}^{2}+F_{a m}^{2}} \quad(m=1 \sim 3)
\end{aligned}
$$

とする。

ここで $\mu_{s m}$ および $\nu_{s m}$ はそれぞれ球面ローラとロー ラ軸間の軸方向の滑り摩擦係数およびローラ軸まわり の回転運動の等価摩擦係数である.

$2 \cdot 3$ 球面ローラがローラ溝上を滑る場合 球面 ローラがローラ溝上を滑る場合には, 球面ローラとロ ーラ溝間の溝方向の滑り摩擦係数を $\mu_{y m}$ とするとき, 4 章の条件式 (37) に従って $F_{y m}$ をローラ溝方向の摩擦 力ー $\mu_{y m} F_{C m}$ で置き換え, 同時に $-\nu_{s m} F_{u m}^{*}$ をローラ 軸まわりの反モーメント $M_{s m}$ で置き換えるものとする.

\section{3. カおよびモーメントの釣合い条件}

\section{$3 \cdot 1$ 球面ローラに作用する力とモーメントの釣合} い 単位ベクトル $\boldsymbol{a}$ 押よび $\boldsymbol{s}_{m}$ の単位ベクトル $\boldsymbol{n}_{m}$, $\boldsymbol{j}, \boldsymbol{t}_{m}(m=1 \sim 3)$ 方向の成分をそれぞれ $a_{n m}, a_{y}, a_{t m}$ お よび $s_{n m}, s_{y m}, s_{t m}$ とする. 球面ローラが転がる場合の 第 1 ，第 2 および第 3 番めの球面ローラに作用する力 およびモーメントの釣合い条件式は,

$\cos \delta_{m} \fallingdotseq 1, \quad$ sin $\delta_{m} \fallingdotseq \delta_{m}$

と近似することにより次のように得られる。 


$$
\begin{aligned}
& F_{c m}+F_{u m}\left\{\cos ^{2} \phi_{m}+\cos \beta \sin ^{2} \phi_{m}\right. \\
& \left.-(1-\cos \beta) \sin \phi_{m} \cos \phi_{m} \delta_{m}\right\} \\
& +F_{a m} a_{n m}-\mu_{s m} F_{u m}^{*} s_{n m}=0 \\
& F_{y m}+F_{u m} \sin \beta \sin \phi_{m}+F_{a m} a_{y} \\
& -\mu_{s m} F_{u m}^{*} S_{y m}=0 \\
& -\mu_{t m} F_{c m}+F_{u m}\left\{(1-\cos \beta) \sin \phi_{m} \cos \phi_{m}\right. \\
& \left.+\left(\cos ^{2} \phi_{m}+\cos \beta \sin ^{2} \phi_{m}\right) \delta_{m}\right\} \\
& +F_{a m} a_{t m}-\mu_{s m} F_{u m}^{*} S_{t m}=0 \\
& -\nu_{n m} F_{C m}+M_{u m}\left\{\cos ^{2} \phi_{m}+\cos \beta \sin ^{2} \phi_{m}\right. \\
& \left.-(1-\cos \beta) \sin \phi_{m} \cos \phi_{m} \delta_{m}\right\} \\
& +M_{a m} a_{n m}-\nu_{s m} F_{u m}^{*} S_{n m}=0 \\
& \mu_{t m} F_{C m} b+M_{u m} \sin \beta \sin \phi_{m} \\
& +M_{a m} a_{y}-\nu_{s m} F_{u m}^{*} s_{y m}=0 \\
& F_{y m} b+M_{u m}\left\{(1-\cos \beta) \sin \phi_{m} \cos \phi_{m}\right. \\
& \left.+\left(\cos ^{2} \phi_{m}+\cos \beta \sin ^{2} \phi_{m}\right) \delta_{m}\right\} \\
& +M_{a m} a_{t m}-\nu_{s m} F_{u m}^{*} S_{t m}=0
\end{aligned}
$$

球面ローラがローラ溝上を滑る場合の条件式は， $F_{y m}$ を摩擦力 $-\mu_{y m} F_{C m}$ で置き換え, 同時に $-\nu_{s m} F_{u m}^{*}$ を反モーメント $M_{s m}$ で置き換えて得られる式となる.

$3 \cdot 2$ ハウジングに作用するカとモーメントの釣合 い ハウジング・入力軸に作用する力执よびモーメ ントの釣合い条件式はそれぞれ次のようになる。

$$
\begin{aligned}
& F_{o x} \boldsymbol{i}+F_{o y} \boldsymbol{j}+F_{o z} \boldsymbol{k}+F_{c 1} \boldsymbol{n}_{1}+F_{C 2} \boldsymbol{n}_{2}+F_{C 3} \boldsymbol{n}_{3} \\
& \quad+\left(F_{y 1}+F_{y 2}+F_{y 3}\right) \boldsymbol{j} \\
& \quad-\mu_{t 1} F_{c 1} \boldsymbol{t}_{1}-\mu_{t 2} F_{c 2} \boldsymbol{t}_{2}-\mu_{t 3} F_{c 3} \boldsymbol{t}_{3}=0 \cdots \cdots(13) \\
& M_{o x} \boldsymbol{i}+M_{o y} \boldsymbol{j}+M_{o z} \boldsymbol{k} \\
& \quad+\sum_{m=1}^{3}\left\{-\nu_{n m} F_{c m} \boldsymbol{n}_{m}-y_{c m} F_{c m} \sin \phi_{m}^{*} \boldsymbol{i}\right. \\
& \quad+r \cos \delta_{m} F_{c m} \boldsymbol{j}-y_{c m} F_{c m} \cos \psi_{m}^{*} \boldsymbol{k}-z_{c m} F_{y m} \boldsymbol{i} \\
& \quad+x_{c m} F_{y m} \boldsymbol{k}-y_{c m} \mu_{t m} F_{c m} \cos \psi_{m}^{*} \boldsymbol{i} \\
& \quad-\left(r \sin \delta_{m}-\frac{d}{2}\right) \mu_{t m} F_{c m} \boldsymbol{j} \\
& \quad+y_{c m} \mu_{t m} F_{c m} \sin \phi_{m}^{*} \boldsymbol{k}=0 \cdots \cdots \cdots \cdots \cdots \cdots(14)
\end{aligned}
$$

球面ローラがローラ溝上を滑る場合の条件式は $F_{y m}$ を摩擦力 $-\mu_{y m} F_{C m}$ で置き換えて得られる式となる.

$3 \cdot 3$ トリポードに作用するカとモーメントの釣合 い 単位ベクトル $\boldsymbol{a}, \boldsymbol{s}_{m}$ およびそれらに直交する単 位ベクトル $\boldsymbol{u}_{m}$ の $x$ 軸， $y$ 軸抒よび $z$ 軸方向の成分を それぞれ $a_{x}, a_{y}, a_{z} ; s_{m x}, s_{m y}, s_{m z}$ および $u_{m x}, u_{m y}$, $u_{m z}$ とする. 球面ローラが転がる場合のトリポード・ 出力軸に作用する力およびモーメントの釣合い条件式 はそれぞれ次のようになる。

$$
\begin{aligned}
& F_{B x} \boldsymbol{i}+F_{B y} \boldsymbol{j}+F_{B z} \boldsymbol{k}+F_{u 1} \boldsymbol{u}_{1}+F_{u 2} \boldsymbol{u}_{2}+F_{u 3} \boldsymbol{u}_{3} \\
& \quad+\left(F_{a 1}+F_{a 2}+F_{a 3}\right) \boldsymbol{a}
\end{aligned}
$$

$$
\begin{aligned}
& \quad-\mu_{s 1} F_{u 1}^{*} \boldsymbol{s}_{1}-\mu_{s 2} F_{u 2}^{*} \boldsymbol{s}_{2}-\mu_{s 3} F_{u 3}^{*} \boldsymbol{s}_{3}=0 \cdots \cdots(1 \\
& M_{B} \boldsymbol{a}+\left(y_{B} F_{B z}-z_{B} F_{B y}\right) \boldsymbol{i}+z_{B} F_{B x} \boldsymbol{j}-y_{B} F_{B x} \boldsymbol{k} \\
& \quad+\sum_{m=1}^{3}\left[M_{u m} \boldsymbol{u}_{m}+M_{a m} \boldsymbol{a}-\nu_{s m} F_{u m}^{*} \boldsymbol{s}_{m}\right. \\
& \quad+F_{u m}\left\{\left(y_{R m} u_{m z}-z_{R m} u_{m y}\right) \boldsymbol{i}+\left(z_{R m} u_{m x}\right.\right. \\
& \left.\left.\quad-x_{R m} u_{m z}\right) \boldsymbol{j}+\left(x_{R m} u_{m y}-y_{R m} u_{m x}\right) \boldsymbol{k}\right\} \\
& \quad+F_{a m}\left\{\left(y_{R m} a_{z}-z_{R m} a_{y}\right) \boldsymbol{i}+\left(z_{R m} a_{x}-x_{R m} a_{z}\right) \boldsymbol{j}\right. \\
& \left.\quad+\left(x_{R m} a_{y}-y_{R m} a_{x}\right) \boldsymbol{k}\right\}-\mu_{s m} F_{u m}^{*}\left\{\left(y_{R m} S_{m z}\right.\right. \\
& \left.\quad-z_{R m} s_{m y}\right) \boldsymbol{i}+\left(z_{R m} s_{m x}-x_{R m} s_{m z}\right) \boldsymbol{j} \\
& \left.\left.\quad+\left(x_{R m} S_{m y}-y_{R m} s_{m x}\right) \boldsymbol{k}\right\}\right]=0 \cdots \cdots \cdots \cdots \cdots \cdots(16)
\end{aligned}
$$

球面ローラがローラ溝上を滑る場合の条件式は ー $\nu_{s m} F_{u m}^{*}$ を反モーメント $M_{s m}$ で置き換えて得られる 式となる。

\section{4. 力 学 解 析}

$4 \cdot 1$ 解析手順 三つの球面ローラ, トリポード およびハウジングに作用する力とモーメントの釣合い 条件式は合計で 30 個となる。トリポード軸まわりの モーメント $M_{B}$ を既知量とするとき，これらの条件式 は，27個の力とモーメントおよび球面ローラからロー ラ溝に作用する力の方向を表す角 $\delta_{1}, \delta_{2}, \delta_{3}$ の 30 個の 未知量に関する非線形の連立方程式を構成する。

30 個の未知量

- $F_{O x}, F_{O y}, F_{O z}, M_{o x}, M_{O y}, M_{O z}$

- $F_{B x}, \quad F_{B y}, \quad F_{B z}$

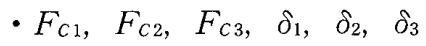

- $F_{a 1}, F_{a 2}, F_{a 3}, M_{a 1}, M_{a 2}, M_{a 3}$

- $F_{u 1}, \quad F_{u 2}, F_{u 3}, M_{u 1}, M_{u 2}, M_{u 3}$

・ $F_{y 1}$ または $M_{s 1}, F_{y 2}$ または $M_{s 2}$,

$F_{33}$ または $M_{s 3}$

球面ローラが転がる場合の球面ローラに作用する力 とモーメントの釣合い条件式(11)，(12) は，両辺を $F_{c m}$ で割り,

$$
\left.\begin{array}{l}
\lambda_{1}=\frac{F_{y m}}{F_{c m}}, \quad \lambda_{2}=\frac{F_{u m}}{F_{c m}}, \quad \lambda_{3}=\frac{F_{a m}}{F_{C m}} \\
\lambda_{4}=\frac{M_{u m}}{F_{c m}}, \quad \lambda_{5}=\frac{M_{a m}}{F_{c m}}
\end{array}\right\}
$$

とおけば, $\lambda_{1}, \lambda_{2}, \cdots, \lambda_{5}$ および $\delta_{m}$ に関する非線形の 6 元の連立方程式となる.

$$
\text { ところで, }
$$$$
F_{u m}^{*} \fallingdotseq F_{u m}
$$

と近似してもトリポード形等速継手の力学特性の本質 は変わらないと考えられるので, 非線形の連立方程式 (11)，(12)は，それらの左辺を

$$
\begin{aligned}
& f_{l}\left(\lambda_{1}, \lambda_{2}, \lambda_{3}, \lambda_{4}, \lambda_{5}, \delta_{m}\right) \\
& \quad=a_{l 1} \lambda_{1}+a_{l 2} \lambda_{2}+a_{l 3} \lambda_{3}+a_{l 4} \lambda_{4}+a_{l 5} \lambda_{5} \\
& \quad+\delta_{m}\left(a_{l 6} \lambda_{2}+a_{l 7} \lambda_{3}+a_{l 8} \lambda_{4}+a_{l 9} \lambda_{5}\right)+a_{l 10}
\end{aligned}
$$




$$
(l=1 \sim 6)
$$

と表すことにより次のように線形近似することができ る.

$$
\begin{aligned}
& {\left[\begin{array}{llllll}
b_{11} & b_{12} & b_{13} & b_{14} & b_{15} & b_{16} \\
b_{21} & b_{22} & b_{23} & b_{24} & b_{25} & b_{26} \\
b_{31} & b_{32} & b_{33} & b_{34} & b_{35} & b_{36} \\
b_{41} & b_{42} & b_{43} & b_{44} & b_{45} & b_{46} \\
b_{51} & b_{52} & b_{53} & b_{54} & b_{55} & b_{56} \\
b_{61} & b_{62} & b_{63} & b_{64} & b_{65} & b_{66}
\end{array}\right]} \\
& \times\left[\begin{array}{c}
\lambda_{1}-\lambda_{10} \\
\lambda_{2}-\lambda_{20} \\
\lambda_{3}-\lambda_{30} \\
\lambda_{4}-\lambda_{40} \\
\lambda_{5}-\lambda_{50} \\
\delta_{m}-\delta_{m 0}
\end{array}\right]=-\left[\begin{array}{c}
f_{10} \\
f_{20} \\
f_{30} \\
f_{40} \\
f_{50} \\
f_{60}
\end{array}\right]
\end{aligned}
$$

ここで, $\lambda_{10}, \lambda_{20}, \cdots, \delta_{m 0}$ は $\lambda_{1}, \lambda_{2}, \cdots, \delta_{m}$ の近似解であ り, $f_{10}, f_{20}, \cdots, f_{60}$ はそのときの関数 $f_{l}(l=1 \sim 6)$ の值 である. $b_{i j}(i=1 \sim 6, j=1 \sim 6)$ は $a_{i j}(i=1 \sim 6, j=1$ １0）と近似解から定まる值である。

近似解 $\lambda_{10}, \lambda_{20}, \cdots, \delta_{m 0}$ は， $\phi=0$ の位置に打いて解析 的に求め, この位置より $\phi$ が一定刻み角ずつ増加した 位圆に対しては 1 刻み角前の位置の $\lambda_{1}, \lambda_{2}, \cdots, \delta_{m}$ の解

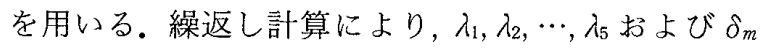
の值が決定されると, $F_{y m}, F_{u m}, F_{a m}, M_{u m}, M_{a m}$ は $F_{c m}$ で表される。

三つの球面ローラに対する $\lambda_{i}(i=1 \sim 5)$ と $\delta_{1}, \delta_{2}$ お よび $\delta_{3}$ を求めれば, トリポードおよびハウジングに 作用する力とモーメントの釣合い条件式 (13) （16) は $F_{C 1}, F_{C 2}, F_{C 3}, F_{B x}, F_{B y}, F_{B z}, F_{O x}, F_{O y}, F_{O z}, M_{O x}, M_{O y}$, $M_{O z}$ に関する線形 12 元の連立方程式となり,この連 立方程式を解くことにより 12 個の力とモーメントを 求めることができる。

球面ローラが滑る場合の球面ローラに作用する力と モーメントの釣合い条件式も同様の手法で解くことが でき, $M_{s m}, F_{u m}, F_{a m}, M_{u m}, M_{a m}$ は $F_{C m}$ で表される。

$4 \cdot 2$ 球面ローラのローラ軸に対する回転方向 球面ローラの中心は八ウジングのローラ溝に対して 1 回転中に 1 往復運動する.このとき，球面ローラと ローラ溝の接点はトリポードのローラ軸に対して 1 回 転中に軸方向に 2 往復運動すると共に軸まわりに1摇 動運動するので, 球面ローラのローラ軸に対する回転 方向はその往復運動の端点から少し離れたところで反 転することになる。

$4 \cdot 2 \cdot 1$ ローラ溝との転がり運動による球面ローラ の回転速度 球面ローラのローラ溝に対する傾き角 を $\theta_{\mathrm{I}}$ とすると次式が成立する。

$$
\cos \left(\theta_{\mathrm{l}}+\frac{\pi}{2}\right)=s_{m} \cdot \boldsymbol{j}=-\sin \beta \cos \phi_{m}
$$

ゆえに，

$$
\sin \theta_{\mathrm{I}}=\sin \beta \cos \phi_{m}
$$

球面ローラとローラ溝の溝方向相対運動が転がり運 動である場合の球面ローラの回転角を出力角の関数と して $\theta_{R}\left(\phi_{1}\right)$ と表すとき, 球面ローラの中心の微小変 位 $\Delta h_{m}$ に対応する微小回転角 $\Delta \theta_{R}$ 注次式で与えられ る.

$$
\Delta \theta_{R}=\Delta h_{m} / b \cos \theta_{\mathrm{I}}
$$

よって, 転がり運動する球面ローラのローラ溝に対 する回転速度は，ローラ溝に対する球面ローラの中心 の変位 $h_{m}\left(\phi_{1}\right)$ を用いて次式で算出される.

$$
\frac{d \theta_{R}}{d \phi_{1}}=\frac{d h_{m}\left(\phi_{1}\right) / d \phi_{1}}{b \sqrt{1-\left(\sin \beta \cos \phi_{m}\right)^{2}}}
$$

$4 \cdot 2 \cdot 2$ ローラ軸が傾斜平面内で回転することによ る球面ローラの回転速度 球面ローラの中心を $\mathrm{R}_{m}$ を原点とし，各軸が静止直交座標系と同じ方向，向き をもつ動直交座標系を $\mathrm{R}_{m}-\boldsymbol{i j} \boldsymbol{k}$ とするとき，ローラ 軸と出力軸(トリポードの.中心線)に直交する方向を表 す単位ベクトルは次式で与えられる。

$$
\boldsymbol{a} \times \boldsymbol{s}_{m}=\cos \phi_{m} \boldsymbol{i}+\sin \beta \cos \phi_{m} \boldsymbol{j}
$$$$
-\cos \beta \cos \phi_{m} \boldsymbol{k}
$$

ローラ軸が傾斜平面内で回転することによる球面口 ーラのローラ軸に対する標準回転速度を求めるため,

$$
\phi_{m} \fallingdotseq \phi_{m}, \quad \delta_{m}=0
$$

とすると, 球面ローラとローラ溝の接点における球面 ローラの法線方向を表す単位べクトルは次式となる。

$$
\boldsymbol{n}_{m}=\cos \phi_{m} \boldsymbol{i}-\sin \phi_{m} \boldsymbol{k}
$$

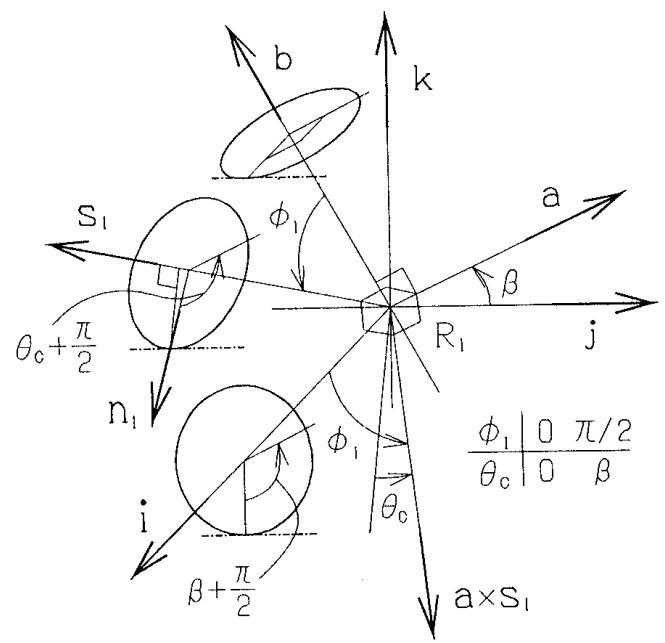

Fig. 4 Relative rotation of the contact point between the spherical roller and the roller groove about the roller axis 
球面ローラとローラ溝の接点からローラ軸に下ろし た垂線の方向を表す単位べクトルは次式で与えられ る.

$$
\begin{aligned}
& \frac{\boldsymbol{n}_{m}-\left(\boldsymbol{n}_{m} \cdot \boldsymbol{s}_{m}\right) \boldsymbol{s}_{m}}{\left|\boldsymbol{n}_{m}-\left(\boldsymbol{n}_{m} \cdot \boldsymbol{s}_{m}\right) \boldsymbol{s}_{m}\right|} \\
& \quad=\left[\cos \phi_{m}\left\{1-(1-\cos \beta) \sin ^{2} \phi_{m}\right\} \boldsymbol{i}\right. \\
& \quad+\sin \beta(1-\cos \beta) \cos ^{2} \phi_{m} \sin \phi_{m} \boldsymbol{j} \\
& \left.\quad-\sin \phi_{m}\left\{1+\cos \beta(1-\cos \beta) \cos ^{2} \phi_{m}\right\} \boldsymbol{k}\right] \\
& \quad / \sqrt{1-(1-\cos \beta)^{2} \cos ^{2} \phi_{m} \sin ^{2} \phi_{m}} \ldots \ldots \ldots .
\end{aligned}
$$

球面ローラとローラ溝の接点のトリポードのローラ 軸に対する回転角 $\theta_{C}$ は, 式(28)の単位べクトルと単 位べクトル $\boldsymbol{a} \times \boldsymbol{s}_{m}$ のなす角であるので近似的に次式 が成立する (図 4 参照).

$\cos \theta_{c} \fallingdotseq 1-(1-\cos \beta) \sin ^{2} \phi_{m}$ ゆえに，

$$
\theta_{C} \fallingdotseq \sin ^{-1}\left(\sin \beta \sin \phi_{m}\right)
$$

式(30)の両辺を $\phi_{1}$ で微分すると, 入力軸(ハウジン グの中心線)とトリポードのローラ軸のなす角が変化 することによる球面ローラのローラ軸に対する回転速 度が次のように求まる。

$$
\frac{d \theta_{c}}{d \phi_{1}}=\frac{\sin \beta \cos \phi_{m}}{\sqrt{1-\left(\sin \beta \sin \phi_{m}\right)^{2}}}
$$

$4 \cdot 2 \cdot 3$ 球面ローラに作用する摩擦力の方向 八 ウジングのローラ溝に対して溝方向に転がっている場 合の球面ローラは,トリポードのローラ軸に対しては 次の関数の正, 負により転がる方向を反転する.

$$
\bar{\zeta}_{R}\left(\phi_{1}\right)=\operatorname{sgn}\left\{\frac{d \theta_{R}\left(\phi_{1}\right)}{d \phi_{1}}-\frac{d \theta_{c}\left(\phi_{1}\right)}{d \phi_{1}}\right\}
$$

$4 \cdot 3$ 摩擦係数 等速継手が 1 回転する間に, 球 面ローラは相対的にハウジングのローラ溝上を 1 往復 運動し，かつ姿勢も1摇動する.さらに，球面ローラ はトリポードのローラ溝上を 2 往復する。このため, ローラ溝执よびローラ軸から球面ローラに作用する摩 擦力, 摩擦モーメントの方向は 1 回転中にそれぞれ 1 回抢よび 2 回だけ変化する。

また，球面ローラとローラ溝およびローラ軸間には クリアランスがあり, 摩擦力, 摩擦モーメントの反転 は滑らかな曲線に沿って行われるものとする。

よって，ハウジング，トリポードおよび球面ローラ に作用する力とモーメントの釣合い条件式中に含まれ る摩擦係数は, 球面ローラと八ウジングおよびトリポ ードの相対速度の正, 真, さらに球面ローラのローラ 軸に対する回転方向に従って次式で与える。

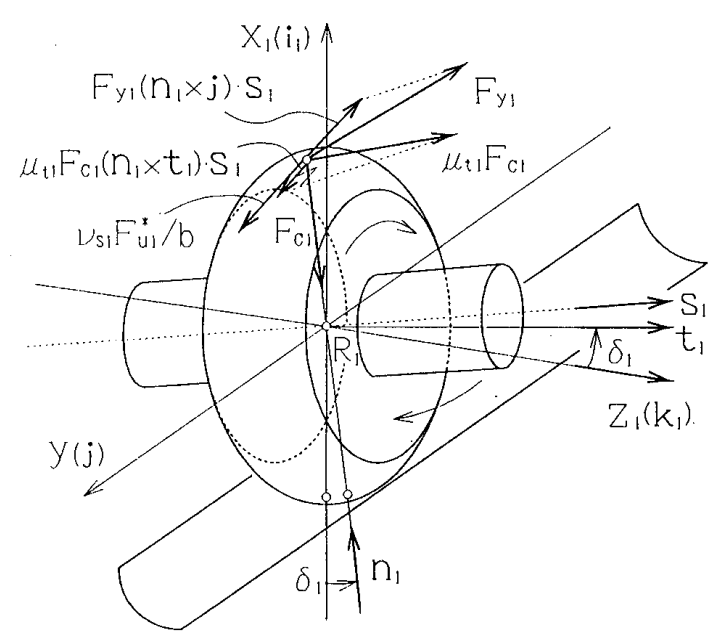

Fig. 5 Forces acting on the spherical roller and the equivalent force at the contact point

$$
\begin{aligned}
& \left.\begin{array}{l}
\mu_{y m}=-\zeta_{R m} \mu_{y} \\
\mu_{t m}=-\zeta_{s m} \mu_{t} \\
\nu_{n m}=\zeta_{h m} \nu_{n} \\
\mu_{s m}=-\zeta_{s m} \mu_{s} \\
\nu_{s m}=\zeta_{R m} \nu_{s}
\end{array}\right\} \\
& \left.\begin{array}{l}
\zeta_{R m}=\frac{2}{\pi} \tan ^{-1}\left\{10 \bar{\zeta}_{R}\left(\phi_{1}\right)\right\} \\
\zeta_{n m}=\frac{2}{\pi} \tan ^{-1}\left\{10 \frac{d h_{m} / d \phi_{1}}{\left(d h_{m} / d \phi_{1}\right)_{\max }}\right\} \\
\zeta_{s m}=\frac{2}{\pi} \tan ^{-1}\left\{10 \frac{d s_{m} / d \phi_{1}}{\left(d s_{m} / d \phi_{1}\right)_{\max }}\right\}
\end{array}\right\}
\end{aligned}
$$$$
\text { ここに, }
$$

$4 \cdot 4$ 球面ローラが転がる条件 球面ローラが図 5 の矢印の方向に回転し始める瞬間におけるローラ溝 から球面ローラに作用する摩擦力扔よび摩擦モーメン トによるローラ軸まわりのモーメントは, 球面ローラ とローラ溝間の溝方向の滑り摩擦係数を $\mu_{y m}$ とする とき次式で与えられる。

$$
\begin{aligned}
\left\{b \boldsymbol{n}_{m} \times\left(-\mu_{y m} F_{c m} \boldsymbol{j}+\mu_{t m} F_{c m} \boldsymbol{t}_{m}\right)\right. \\
\left.\quad+\nu_{n m} F_{c m} \boldsymbol{n}_{m}\right\} \cdot\left(-\boldsymbol{s}_{m}\right) \\
\quad=b F_{c m}\left\{\mu _ { y m } \left(\sin \phi_{m} \sin \phi_{m}^{*}\right.\right. \\
\left.\quad+\cos \beta \cos \phi_{m} \cos \phi_{m}^{*}\right) \\
\left.\quad-\mu_{t m} \sin \beta \cos \phi_{m}\right\}-\nu_{n m} F_{c m}\left(\sin \phi_{m} \cos \phi_{m}^{*}\right. \\
\left.\quad-\cos \beta \cos \phi_{m} \sin \phi_{m}^{*}\right) \cdots \cdots \cdots \ldots \ldots \ldots \cdots(35
\end{aligned}
$$

ローラ軸加ら球面ローラに作用する力によるローラ 軸まわりの摩擦モーメントは次式で与えられる。

$$
\nu_{s m} F_{u m}^{*} \boldsymbol{s}_{m} \cdot\left(-\boldsymbol{s}_{m}\right)=-\nu_{s m} F_{u m}^{*}
$$

よって, 球面ローラが転がる条件は次式となる.

$\mu_{y m}\left(\sin \phi_{m} \sin \phi_{m}^{*}+\cos \beta \cos \phi_{m} \cos \phi_{m}^{*}\right)$

$-\nu_{n m}\left(\sin \phi_{m} \cos \phi_{m}^{*}-\cos \beta \cos \phi_{m} \sin \phi_{m}^{*}\right) / b$

$-\mu_{t m} \sin \beta \cos \phi_{m}-\nu_{s m} F_{u m}^{*} / b F_{c m}>0 \cdots$ (37) 


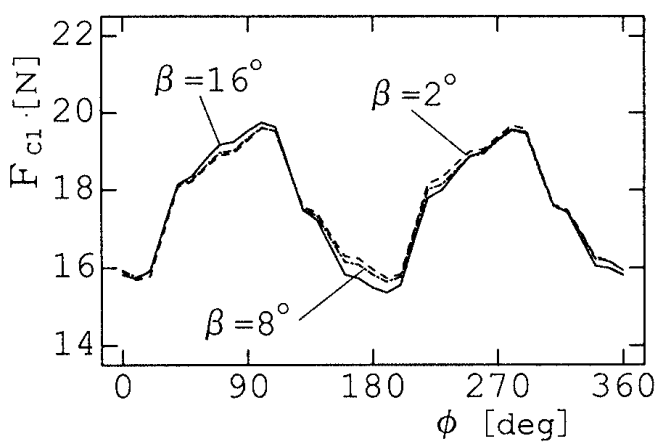

Fig. 6 Normal forces acting on the rolling spherical roller

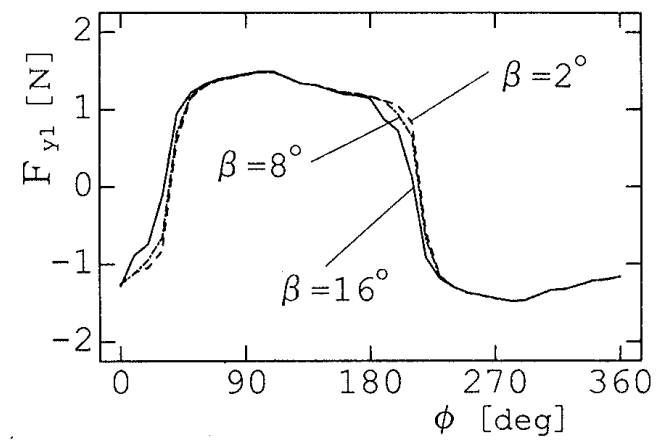

Fig. 7 Forces acting on the rolling spherical roller in the direction of the housing axis (the groove thrust force)

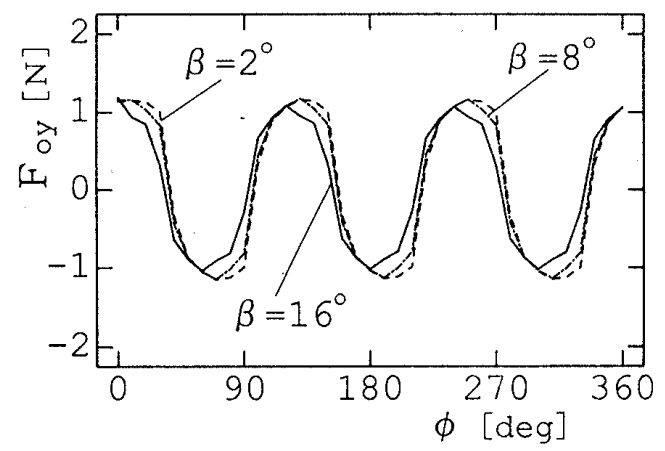

Fig. 8 Housing thrust forces (the summation of three groove thrust force) in the case where spherical rollers are sliding

\section{5. シミュレーションおよび実験解析}

$5 \cdot 1$ シミュレーション トリポード形等速継手 の機構定数および軸交差角を，

$r_{1}=r_{2}=r_{3}=18.5 \mathrm{~mm}$

$b_{1}=b_{2}=b_{3}=14 \mathrm{~mm}$

$d_{1}=d_{2}=d_{3}=28 \mathrm{~mm}$

$a=500 \mathrm{~mm}, \quad \bar{\beta}=2^{\circ}, 4^{\circ}, \cdots, 16^{\circ}$

$x_{B}=0 \mathrm{~mm}, \quad y_{B}=490.5 \mathrm{~mm}, z_{B}=138 \mathrm{~mm}$

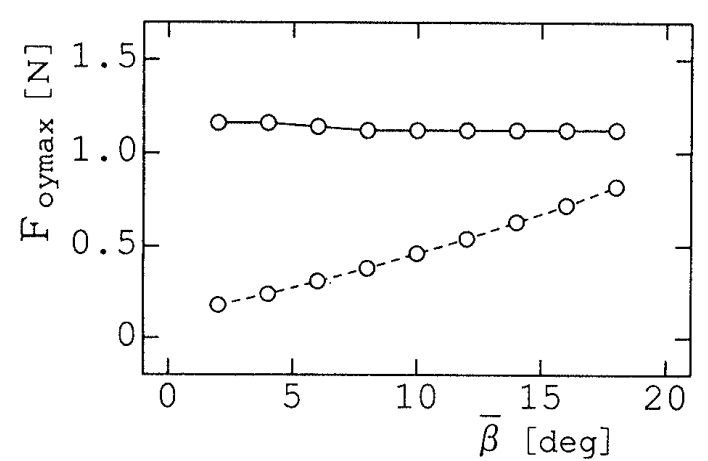

Fig. 9 Variation of the maximum value of the housing thrust force with the joint angle $\bar{\beta}$ in cases where spherical rollers are sliding and these are rolling

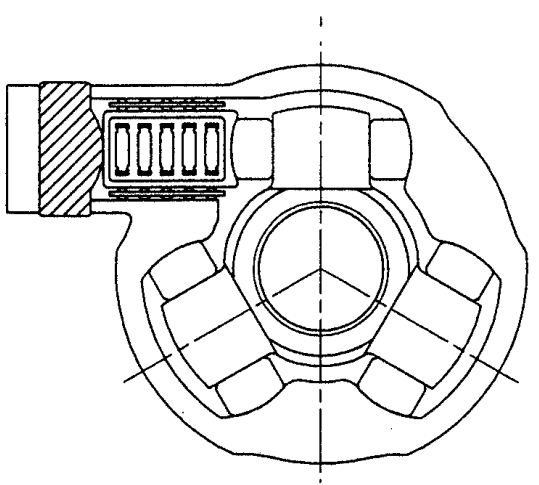

Fig. 10 Housing for measuring the normal force of the spherical roller

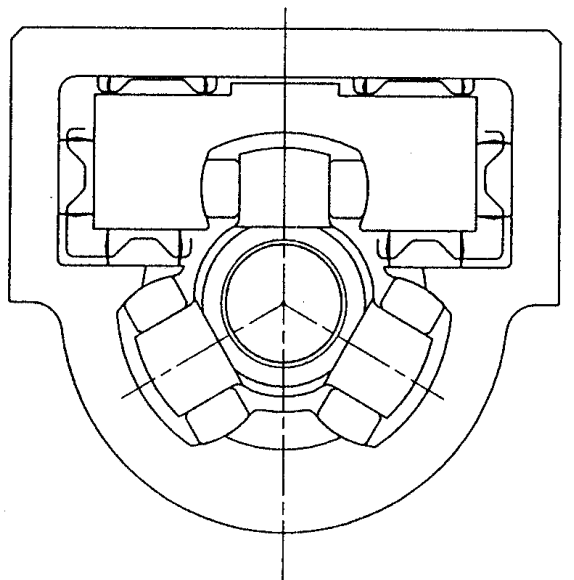

Fig. 11 Housing for measuring the groove thrust force

とする.

$5 \cdot 1 \cdot 1$ 球面ローラが滑る場合 球面ローラとロ ーラ溝およびローラ軸の間の摩擦係数, 摩擦係数 $\times$ 垂 直距離を

$$
\begin{aligned}
& \mu_{y}=0.08, \quad \mu_{t}=0.09, \quad \mu_{s}=0.09 \\
& \nu_{n}=0.08 \times 4.8, \quad \nu_{s}=0.16 \times 7.5
\end{aligned}
$$

と設定し, 出力トルクを $M_{B}=1 \mathrm{Nm}$ に与えるときの 第 1 番めの球面口ーラの法線力 $F_{C 1}$, 第 1 番めのロー 


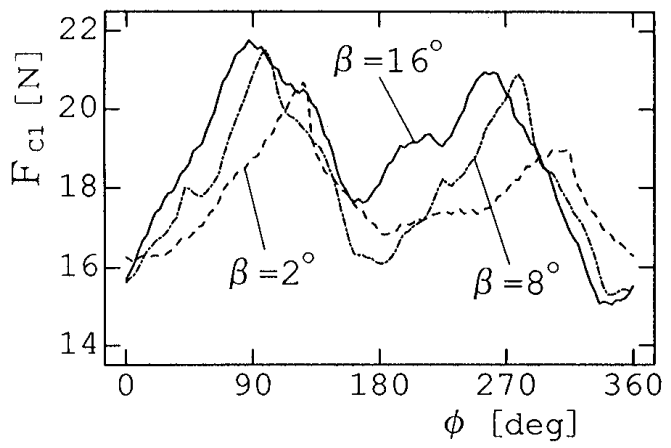

Fig. 12 Measured values of the normal force acting on the spherical roller

ラ溝の反力 $F_{y 1}$ または摩擦力 $-\mu_{y m} F_{C 1}$ (以下, この力 をローラ溝スラスト力と呼ぶ）およびハウジングのス ラスト力 $F_{O y}$ をそれぞれ図 6〜8 に示す。また, 八ウ ジングスラスト力の最大值は，図 9 の実線で示すよう に，軸交差角に対してほぼ一定值であった。

$5 \cdot 1 \cdot 2$ 球面ローラが転がる場合＼cjkstart球面ローラと ローラ軸が針状ころを介して円筒対偶されているもの とし, $5 \cdot 1 \cdot 1$ 項の摩擦係数, 摩擦係数 $\times$ 垂直距離のう ちの $\nu_{s}$ の值を $0.16 \times 7.5$ から $0.02 \times 7.5$ に変更して, 第 1 番めの球面口ーラの法線力 $F_{C 1}$, 第 1 番めの口ー ラ溝スラスト力 $F_{y 1}$ または $-\mu_{y m} F_{C 1}$ および八ウジン

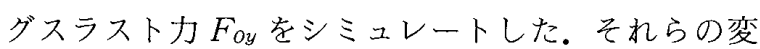
化特性は球面ローラが滑る場合とほぼ同じであった。 ハウジングスラスト力の最大値は軸交差角に封して, 図 9 に破線で示すように, 軸交差角に対してほぼ直線 的に増加した.

$5 \cdot 2$ 実験解析 一つのローラ溝の片面を，図 10 に示すように, ハウジングのピッチ円の接線方向に運 動可能な長方形ブロックの端面に形成し，この長方形 ブロックの反対側の端面に圧縮用力センサを挿入して 球面ローラの法線力を測定した。 また，一つのローラ 溝を, 図 11 に示すように, 八ウジングの中心線方向 (紙面に垂直な方向)に運動可能な長方形ブロックの内 部に形成し，この長方形ブロックの運動方向の片端面 に圧縮・引張用力センサを挿入してローラ溝のスラス ト力を测定した。

球面ローラの法線力抢よびローラ溝スラスト力測定 用の長方形ブロックの案内面は針状ころを介してハウ ジングに直進対偶されており, 運動方向の摩擦力が十 分に小さいことを確かめている。

測定された球面ローラの法線力を図 12 亿, 第 1 番 めのローラ溝スラストカとその位相をずらした二つの

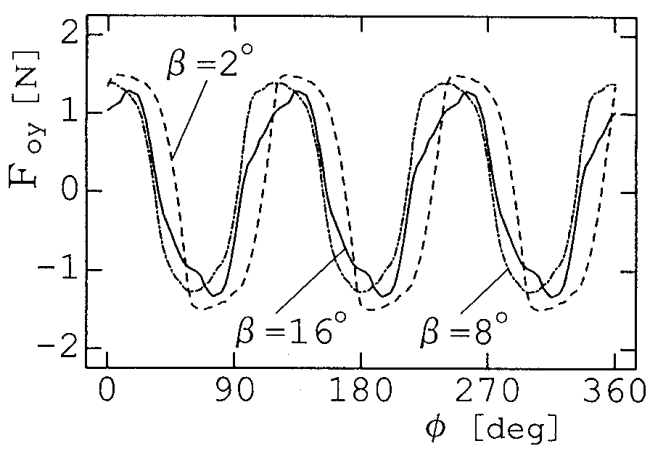

Fig. 13 Measured values of the groove thrust force

力から合成されたハウジングスラストカを図 13 に示 す.

\section{6. 結 言}

（1）トリポード形等速継手の三つの球面ローラ, ハウジングおよびトリポードに作用する力とモーメン トの釣合い条件式を, 球面ローラがローラ溝上を転が る場合扔よび滑る場合について導出した。そして，こ れらの条件式を三つの球面ローラの各々に関する六元 非線形連立方程式とハウジングとトリポードに関する 十二元線形連立方程式に分けて解く解法を確立した。

（2）球面ローラのローラ軸に対する相対回転速度 の算出式を与えるとともに, 球面ローラとローラ溝お よびローラ軸間の相対運動の摩擦係数をパラメータと して, 球面ローラがローラ溝上を転がり運動から滑り 運動に，およびその逆に切り替わる条件を導出した。

（3）球面ローラがローラ溝上を転がる場合および 滑る場合の球面ローラの法線力およびハウジングスラ ストカのシミュレーション結果と実験結果を比較検討 することにより本論文の手法の有効性を確認した。

卒業研究として力学シミュレーションに協力された 1998 年度卒業生大野利晴君に感謝の意を表します。

\section{文献}

(1) Dodge, J. H. and Wagner, E. R., Tripot Universal Joint (End Motion Type), SEA, (1979), 131-140.

（2）木全 圭, 等速ジョイントに扔ける摩擦と潤滑, 潤滑, 31 10 (1986), 13-18.

（3）清水 勝・小林正治・岡村正則, CVJ の起振力低減によ る振動騒音の改善，三菱自動車テクニカルレビュー， 3 (1990), 37-45.

（4）渡辺克巳・川勝 勉・中尾彰一・大野利晴, トリポード 形等速継手のハウジングスラスト力解析, 機講論, No. 991 (1999-7), 383-384. 